\title{
Bewogen (door) onderwijs
}

Citation for published version (APA):

Savelberg, H. (2016). Bewogen (door) onderwijs. Maastricht University. https://doi.org/10.26481/spe.20161007hs

Document status and date:

Published: 07/10/2016

DOI:

10.26481/spe.20161007hs

Document Version:

Publisher's PDF, also known as Version of record

\section{Please check the document version of this publication:}

- A submitted manuscript is the version of the article upon submission and before peer-review. There can be important differences between the submitted version and the official published version of record.

People interested in the research are advised to contact the author for the final version of the publication, or visit the DOI to the publisher's website.

- The final author version and the galley proof are versions of the publication after peer review.

- The final published version features the final layout of the paper including the volume, issue and page numbers.

Link to publication

\footnotetext{
General rights rights.

- You may freely distribute the URL identifying the publication in the public portal. please follow below link for the End User Agreement:

www.umlib.nl/taverne-license

Take down policy

If you believe that this document breaches copyright please contact us at:

repository@maastrichtuniversity.nl

providing details and we will investigate your claim.
}

Copyright and moral rights for the publications made accessible in the public portal are retained by the authors and/or other copyright owners and it is a condition of accessing publications that users recognise and abide by the legal requirements associated with these

- Users may download and print one copy of any publication from the public portal for the purpose of private study or research.

- You may not further distribute the material or use it for any profit-making activity or commercial gain

If the publication is distributed under the terms of Article $25 \mathrm{fa}$ of the Dutch Copyright Act, indicated by the "Taverne" license above, 
Prof. Dr. Hans H.C.M. Savelberg Faculty of Health, Medicine and Life Sciences

\section{BEWOGEN (door) ONDERWIJS}




\section{BEWOGEN (door) ONDERWIJS}

\section{Inaugurele rede}

Uitgesproken bij de aanvaarding van het ambt van Bijzonder Hoogleraar 'Academisch Onderwijs in Beweging' aan de Faculty of Health, Medicine and Life Sciences.

Maastricht, 7 Oktober 2016

Prof. Dr. Hans H.C.M. Savelberg 


\section{Welkom}

Geachte prorector, geachte leden van het college van toezicht, beste collega's en studenten, lieve vrienden en familie, wat fijn dat jullie de moeite genomen hebben om hier aanwezig te zijn om mijn inaugurele rede aan te horen.

\section{Moed om te bewegen}

De titel van mijn oratie is 'bewogen (door) onderwijs', waarbij 'door' tussen haakjes staat. Als opmerkelijke toehoorder begrijpt $u$ dat ik $u$ twee titels voorgeschoteld heb: 'Bewogen Onderwijs' en 'Bewogen door Onderwijs'. Deze twee titels representeren het werk dat ik de afgelopen jaren gedaan heb en waar ik de komende jaren mee bezig zal zijn. Dat gaat over onderwijs dat in beweging is, onderwijs waarin bewogen wordt en onderwijs dat studenten beweegt om te studeren en dat ook zeker mij beweegt. Maar behalve dat ik u wil onderhouden over mijn passies 'bewegen' en 'onderwijs', is er nog een overkoepelende boodschap die ik u zou willen meegeven. Aan deze foto ziet $u$ dat deze een groot aantal jaren geleden genomen is. $U$ ziet dat er ooit, ook op mijn hoofd haar groeide. Ik ging toen ook regelmatig naar een kapper. Dat was een aardige man, die graag Frans sprak en me ter afscheid altijd bon courage toe wenste. Dat zou je weliswaar kunnen vertalen als 'veel succes', en mogelijk bedoelde hij daar mijn haargroei mee, maar volgens mij bedoelde hij het duidelijk meer in de richting van 'heb veel moed'. Pas veel later ben ik gaan begrijpen wat hij daar echt mee bedoelde. Hij wenste me toe te gaan staan voor de zaken die ik belangrijk vond! De overkoepelende boodschap van deze oratie zal zijn: 'toon moed!'. Confucius vond dat moed is dat doen waarvan je vindt dat het gedaan moet worden. Ik zal u proberen te laten voelen wat ik bedoel met moed. Ik wil u daarom vragen om op te staan; althans voor zover stijve gewrichten, onwillige spieren en andere ongemakken dat toelaten. Ja, dat had u natuurlijk wel verwacht, dat ik u 
op enig moment in dit uur zou laten opstaan. Goed, nu u staat wil ik u het volgende vragen: 'Bekommert u zich om uw gezondheid, vindt u uw gezondheid belangrijk en wilt $u$ uw best doen om gezond te blijven?' Als u antwoord daarop 'ja' is, dan wil ik u vragen om te blijven staan, als u denkt 'lekker zitten is ook wel fijn', gaat u dan gerust zitten. Dan een tweede vraag voor degenen die nog staan: 'Weet $u$ dat lange tijd achtereen zitten ongezond is en dat er veel gezondheidsvoordelen aan staan en bewegen kleven?'. Als u dat niet wist dan vraag ik u om te gaan zitten. Hen die zich wel van die kennis bewust waren wil ik vragen om nog even te blijven staan. Vijf minuten geleden, vlak voor de hoogleraren binnenkwamen heeft de pedel u gevraagd om te gaan staan. Even later zei hij: 'u mag gaan zitten'. Normaal zegt hij 'wilt u plaats nemen?', dat klinkt wat dwingender, maar 'mag' biedt $u$ expliciet een keuzemogelijkheid. $U$ had er dus voor kunnen kiezen om te blijven staan, maar niemand deed dat, ik trouwens ook niet. Ik denk dat moed is, dat doen wat je belangrijk vindt, populair gezegd: to practice what you preach. Het is geenszins mijn bedoeling om u hier het stempel 'niet moedig' op te plakken als u bent gaan zitten; wat ik probeerde te bereiken is, een beetje duidelijk te maken wat moed is. Ik begrijp dat de wereld niet zwart-wit is, dat er vele andere belangen spelen dan 'gezondheid' alleen. Misschien dacht u wel, 'laat ik maar gaan zitten dan zien de mensen achter mij ook iets', of bent u onbekend en misschien een beetje ongemakkelijk met dit soort bijeenkomst, en was uw eerste ingeving 'laat ik maar doen wat iedereen doet'. Allemaal goede ingevingen. $\mathrm{O} j \mathrm{ja}$, als $\mathrm{u}$ nu wilt gaan zitten doe dat gerust. Ik zal in de loop van mijn betoog met name mijn onderwijzende collega's en de universiteit naar hun moed vragen, en mocht u niet tot één van deze categorieën horen dan hoop ik dat $u$ aan het eind van deze oratie een beetje bewuster bent van het belang van moed. 


\section{Kennis en moed}

Ik wil graag terug gaan naar de thema's onderwijs en bewegen en wil het daarbij ook zeker over onderzoek hebben. Binnen de universiteit maken we vaak onderscheid tussen onderzoek en onderwijs. We zien dat als de twee belangrijke taken van de universiteit. Kort door de bocht geformuleerd: we doen onderzoek om kennis te genereren en inzichten te krijgen, en in het onderwijs geven we die kennis door aan jongere generaties en aan mensen die de nieuwe inzichten toepassen. Kennis is dus de handelswaar van universiteiten. Het fijne van kennis is, dat ze ons handelen voorspelbaar maakt. Ik zal proberen uit te leggen wat ik daarmee bedoel. Als je ziek wordt, dat is op zich vervelend, soms zelfs veel meer dan dat, maar dan is het heel prettig dat je naar een arts kunt gaan, die je onderzoekt, vaststelt wat het probleem is, op basis daarvan je een behandeling voorstelt en dat ze weet dat de behandeling zal werken. Dat is voorspelbaarheid. Als uw dokter niet goed weet wat het resultaat zal zijn is dat beslist vervelender. Het genot van voorspelbaarheid geldt voor veel zaken in ons leven, het is fijn om te kunnen vertrouwen op bruggenbouwers, dat ze weten wat ze doen en dat hun constructietheorieën kloppen, dat zonne-energieplantage inderdaad de berekende stroomopbrengst leveren en dat de fysiotherapeut de tape zo plakt dat je weer kunt functioneren of presteren.

Tegenover kennis staan losstaande, inviduele ervaringen die soms positief zijn, maar waar je niet altijd van weet of er een oorzaak-gevolgrelatie aan ten grondslag lag. Er is moed voor nodig om individuele ervaringen aan de kant te zetten en je handelen te baseren op kennis.

Voor het inrichten en verzorgen van onderwijs geldt eveneens dat je dat kunt organiseren op basis van kennis. Ook hierin hebben we de keuze om moedig te zijn, om gewoontegedrag te vervangen door bewezen leerprocessen en onderwijskundige principes. Dat betekent bijvoorbeeld eerst uitzoeken wat het optimale aantal contacturen is voordat je een programma maakt en niet zomaar 30 contacturen inplannen omdat dat 
dat mooi 5 dagen van 6 uur zijn, of omdat dat vroeger ook zo ging. Als ik in onze faculteit om me heen kijk dan constateer ik dat soms in het onderwijs die moed weleens ontbreekt. De literatuur laat zien dat dit in het hoger onderwijs in het algemeen een onderwerp is (Levin, 2010), en niet een uitdaging die alleen bij onze faculteit of universiteit speelt. Ik kan dit niet met hele harde feiten onderbouwen, maar ik heb het gevoel dat onze faculteit juist een positieve uitzondering is. We hebben een grote vakgroep die zich richt op onderzoek van onderwijs, en de instelling van mijn leerstoel en het onderwijscarrierebeleid dat daar aan ten grondslag ligt kan zeker gezien worden als een voorbeeld van facultaire moed in dezen.

Dit ter inleiding om duidelijk te maken wat de waarde van kennis is. Bewegen en onderwijs, dat zijn de onderwerpen die ik met $u$ wil bespreken. Ik zal twee projecten aan de orde laten komen waarin het onderwijs beweegt en we bewogen worden door onderwijs. Daarbij zal ik laten zien hoe kennis en onderzoek een rol spelen in deze projecten.

\section{Bewogen onderwijs, Veranderingen in de curricula BioMedical Sciences}

Op 5 september $\mathrm{jl}$ is het bachelorprogramma BioMedical Sciences, BioMedische Wetenschappen van start gegaan met een nieuw curriculum. De afgelopen jaren is het eerste jaar ontwikkeld; in de komende twee jaar zullen we ook jaar 2 en 3 vorm geven.

Ik zal kort schetsen wat BioMedische Wetenschappen is. Studenten die opgeleid worden tot biomedisch wetenschapper leren om kennis uit de natuurwetenschappen: biologie, scheikunde, natuurkunde en wiskunde te gebruiken en te combineren om medische vragen op te lossen en innovaties in de preventie, diagnose en behandeling van gezondheidsproblemen te ontwikkelen. Biomedische wetenschappers genereren de kennis die artsen en paramedici gebruiken. 
Ik zal u uitleggen wat er veranderd is in het bachelorprogramma BioMedische Wetenschappen, waarom we dachten dat dat nodig was en wat eigenlijk de evidentie, de bewijslast, voor die veranderingen is.

Het nieuwe bachelorcurriculum wordt gekenmerkt door dat:

- het een volledig Engelstalig programma is, dat zich richt op een internationaal samengestelde studentenpopulatie,

- het naast aandacht aan biomedische expertise, de ruimte geeft aan drie andere competenties,

- het studenten (veel) keuzemogelijkheden biedt en daarmee hen de gelegenheid hun opleiding een persoonlijk profiel te geven,

Er zijn vier belangrijke ontwikkelingen die ten grondslag liggen aan deze vernieuwingen:

- werkgevers verwachten andere vaardigheden van afgestudeerden dan 10-20 jaar geleden,

- we maken steeds meer deel uit van een wereldwijde samenleving,

- de hoeveelheid kennis neemt razendsnel toe en het aantal technologische ontwikkelingen explodeert en

- studenten staan anders in het leven, dan enkele decennia geleden.

Ik ga met de schijnbaar eenvoudigste relatie tussen ontwikkeling en ingezette verandering beginnen, die tussen globalisering en de

Engelstaligheid. Globalisering is een ontwikkeling die de laatste 50 jaar is ingezet en gedurende de laatste 20 jaar door de opkomst van internet in een stroomversnelling terecht is gekomen. Om dit te illustreren heb ik hier een plaatje waarin u ziet welke landen voor hun $21^{\mathrm{e}}$ verjaardag bezocht zijn door vier mensen geboren in respectievelijk 1906, 1938, 1962 en 1995, mijn opa, mijn moeder, een van onze dochters en ikzelf. U ziet in één oogopslag dat de jongste meer bereisd is.

Biomedisch zien we dat terug in epidemieën die van de een op de andere dag meereizend in een vliegtuig oceanen oversteken. Dat ging in de tijd van de pest en de Spaanse griep in een ander tempo. In de $14^{\mathrm{e}}$ eeuw 
deed de pest er 4 jaar over om van de oevers van de Middellandse Zee Rusland te bereiken en aan het begin van de vorige eeuw had de Spaanse griep nog 3 tot 4 maanden nodig voor dat traject. Behalve virussen zijn ook producten, diensten, bedrijven en mensen en gedachten en ideeën reislustiger geworden. Voor de komst van internet duurde het minimaal een dag, maar vaak ook een of meerdere weken om een document, een idee naar iemand door te sturen, nu kost dat niet meer dan een druk op een knop. Voor studenten biomedische wetenschappers betekent de globalisering dat ze onvermijdelijk in een internationale omgeving terecht komen, ook als ze bij Nederlandse bedrijven en instituten gaan werken. In die wereld is de voertaal Engels en krijgen ze te maken met mensen uit andere culturen met andere normen en waarden. Om met dergelijke multiculturele uitdagingen om te leren gaan, is het belangrijk dat we studenten met verschillende culturele achtergronden samenbrengen. Om dat mogelijk te maken is het noodzakelijk dezelfde taal te spreken: Engels ligt dan voor de hand.

Als we het hebben over culturele verschillen, dan gaat het niet zo zeer over hele grote zaken, maar vaak juist over kleine dingen. Zo heb ik uit een betrouwbare, Belgische bron vernomen dat, als een Belg 'ja' zegt op de vraag om iets te doen, dan betekent dat 'misschien', en zegt ze 'misschien' dan is dat eigenlijk een manier om 'nee' te zeggen'. In Nederland, nou ja in delen van Nederland zijn we daar directer in. Ik wil niet betogen dat het een beter is dan het ander, maar wel dat het goed is als we ons van dit soort verschillen bewust zijn en er mee leren omgaan. Ik denk dat je daar niet vroeg genoeg mee kunt beginnen. Ik ben dan ook blij dat ruim een derde van de 330 eerstejaars studenten uit het buitenland komt. Ze komen uit ruim dertig verschillende landen verspreid over drie continenten. Rond de start van het academisch jaar was er in de media enige commotie rond het gebruik van Engels als universitaire voertaal. Er werden zorgen geuit over de Engelse taalvaardigheden van docenten, over de gevolgen die dit zou hebben voor de beheersing van de 
Nederlandse taal en er werd geopperd dat financiele redenen de onderliggende drijfveer vormden. Zoals ik hiervoor heb uitlegd heeft onze keuze voor Engels niets met materiële goudmijnen te maken, maar alles met het goud dat te vinden is in de uitwisseling tussen mensen. Dat spreken in een andere taal dan je moederstaal een uitdaging is en gepaard gaat met verlies aan nuance, moeten we daarbij niet uit het oog verliezen. Om daarbij de vinger aan de pols te houden vereisen we van iedereen die in het onderwijs een rol speelt, niet alleen collegegevers, een niveau van beheersing van het Engels dat bij die rol past. Ik ben ook niet bang dat het ten koste gaat van de beheersing van het Nederland; , het leven bestaat uit meer dan alleen onderwijs geven en volgen. Ook in Maastricht en omgeving is het Limburgs niet teloorgegaan doordat er 40 jaar geleden een universiteit opgericht is waar men hoog Hollands sprak. So let's go for an English programme, wir schaffen dass!

Dan de tweede ontwikkeling. Die gaat over de vraag wat verwachten toekomstige werkgevers van afgestudeerd Biomedische wetenschappers? Onderzoek van Tony Wagner van het Innovation Lab van Harvard University geeft antwoord op die vraag. Wagner heeft grote en kleine Amerikaanse werkgevers, variërend van Apple, Siemens en Unilever tot de militaire academie van West Point, de vraag gesteld: wat wil je dat afgestudeerden kennen en kunnen. Zijn bevindingen heeft hij vervolgens samengevat in 7 survival skills, 7 overlevingsvaardigheden (Wagner, 2010). In het kort komt het erop neer dat werkgevers graag zien dat afgestudeerden passie hebben voor dat waar ze mee bezig zijn, dat ze in staat zijn om overtuigend over hun werk te communiceren, dat ze verantwoordelijkheid nemen in multidisciplinaire samenwerkingsverbanden en dat ze een grote dosis verbeeldingskracht meebrengen en nieuwsgierig zijn en openstaan voor onverwachte mogelijkheden. 
Alleen slim zijn is dus niet voldoende, je moet er, als afgestudeerde ook iets van willen maken, willen weten hoe iets werkt en in elkaar steekt en betrokken zijn op de wereld en de mensen daarin.

Uit een vergelijkbaar onderzoek dat het Nederlands Instituut voor Biologie onder Nederlandse werkgevers in de biologische sector uitgevoerde kwamen dezelfde punten naar voren (NIBI, 2014).

In het nieuwe curriculum hebben we een en ander in een viertal competenties vormgegeven. Onze studenten moeten niet alleen een biomedisch expert worden, maar we willen hen ook opleiden tot inspirerende communicatoren en verantwoordelijke samenwerkers, tot nieuwsgierige, gepassioneerde onderzoekers, en tot pro-actieve professionals.

Deze competenties hebben we expliciet onderdeel gemaakt van de eindtermen van de vernieuwde bachelor en daarmee ook van het onderwijs zelf.

De derde reden heeft te maken met wat ik de kennisexplosie noem. We kunnen en weten steeds meer. Wat dit gegeven nog bijzonderder maakt, is dat die kennistoename steeds sneller gaat. Het plaatje achter me is een mooie illustratie van de versnelling van vernieuwing in kennis. Het laat zien hoe lang het duurde voordat een innovatie 50-miljoein gebruikers had. Het duurde 75 jaar voordat 50 miljoen mensen met elkaar verbonden waren via telefoon, de radio had slecht 38 jaar daarvoor nodig, de televisie 13 jaar, internet 4 jaar, populaire apps doen er op dit moment minder dan een maand over om deze limiet te halen. Voor biomedische wetenschappen wordt geschat dat de hoeveelheid kennis elke 7,5 verdubbelt, dat betekent dat we nu $4 x$ meer kennis, leerstof hebben dan 15 jaar geleden, in 2001; en over 15 jaar, als onze afgestudeerden tussen de 35 en 40 jaar zijn, is die hoeveelheid weer verviervoudigd. Dus het idee van een vast omlijnde hoeveelheid kennis is hopeloos achterhaald. Om daar op in te spelen zijn er in het nieuwe programma een groot aantal 
keuzemogelijkheden gecreëerd zodat elke student zijn of haar eigen profiel als BioMedische Wetenschapper kan vormgeven. Ik kom daar zo nog op terug.

Dan hebben we nog een reden onbesproken gelaten. Oudere generaties hebben vaak de neiging om hoofdschuddend over de bloem der natie te spreken, de jeugd van tegenwoordig. Dat gebeurt ook op universiteiten, docenten klagen over een gebrek aan motivatie bij studenten of vinden dat ze in een zesjescultuur leven. Ik geloof niet dat zij anders zijn dan wij waren. Maar wat me opvalt, is dat studenten het vaak in het begin moeilijk hebben, niet zo goed weten wat ze moeten en waarom ze iets moeten of willen. Tegen het eind van een studie als er een echt, echt probleem op tafel komt, een echt project, of een afstudeerthesis, dan zie juist dat ze opbloeien en enthousiast worden, hun intrinsieke motivatie lijkt dan geraakt te zijn. We lijken vaak te denken dat motivatie, intrinsieke motivatie, iets absoluuts is, je hebt het of je hebt het niet, en als je het als student hebt dan ga je er ook $100 \%$ voor. Volgens mij is het gecompliceerder. Ook studenten hebben slechts 24 uur in één dag. In die 24 uur worden ze verleid door een groot scala aan mogelijke activiteiten, de meest verleidelijke activiteiten winnen en krijgen een groter deel van de aandachtskoek. Een belangrijke aandachttrekker zijn de sociale media. Hoe vaak denkt u dat u dagelijks uw smartphone raadpleegt? Gemiddeld 200 keer per dag (Thomas, 2016). Dat betekent niet alleen dat je 200 keer per dag weer opnieuw moet beginnen met waar je mee bezig was, maar ook dat er 200 keer per dag iets of iemand met een voorstel komt om iets anders te doen dan waar je mee bezig was. Naast de sociale media is een andere afleider: de druk die we elkaar opleggen. Tekend daarvoor vond ik dit artikel in de Observant van 25 februari j.l. (de Boer et al., 2016), waarin de druk beschreven wordt die studenten ervaren . Ik vond dat een schokkend stuk. Studenten leven met het idee dat één master niet genoeg is, dat je eigenlijk toch wel twee of drie stages gedaan moet hebben en dat een CV zonder een bestuursjaar weinig waard is. 
Hoewel dit op zich geen onzinnige activiteiten zijn, zijn het allemaal zaken die het focussen op één opleiding niet ten goede komen. Ik ben er van overtuigd dat je in een bestuursjaar heel veel leert, en dat een extra stage zeker ook opweegt tegen welke andere onderwijsvorm dan ook. Maar dan zouden dergelijke activiteiten in een programma geïncorporeerd moeten worden. Waarom niet een bestuursjaar laten tellen als een minor? Als het issue is dat de andere aandachttrekkers aantrekkelijker zijn geworden dan leren in onderwijssituaties, dan kan een maatregel zijn te zorgen dat die andere aandachttrekkers uitbeeld raken; zo zijn er initiatieven om laptops, en telefoons uit onderwijssituaties te weren. Dat zal voor een deel werken, maar het zijn maatregelen gebaseerd op extrinsieke motivatie, straffen of belonen, en daarmee op den duur weinig kansrijk. Daniel Pink (2011) legt in zijn boek Drive overtuigend uit waarom intrinsieke motivatie wel werkt en extrinsieke motivatie, bestraffen en belonen, kansloos is. Het alternatief is om onderwijs aantrekkelijker te maken, zodat het intrinsiek motiverend is. Dat je gaat studeren omdat het leuk is, omdat dat wat aan de orde komt je boeit. Om dit te bereiken, is het volgens de Self Determination Theory van Ryan en Deci (2000) van belang dat het onderwijs studenten de mogelijkheid geeft om zelf te bepalen wat ze bestuderen en willen leren, dat ze onderwerpen als uitdagend ervaren en dat ze de relevantie van wat er geleerd wordt inzien. Ik begon net met de constatering dat studenten opbloeien in hun stageperiode, terwijl ze het begin van een studie vaak verwarrend vinden. Een typische stage voldoet heel goed aan de eisen die Ryan en Deci aan een taak stellen om haar intrinsiek motiverend te laten zijn. Een stage is vaak uitdagend, daarbij is duidelijk waarom iets gedaan moet worden en als student heb je zelf grote controle over hoe en wanneer je iets doet en ook over wat er gedaan moet worden. Dit in tegenstelling tot het typische begin van een studie waarbij onderwijs in blokken georganiseerd is, blokken die door docenten bedacht zijn, en waarvan het niet altijd duidelijk is waarom de betreffende inhoud relevant is. We zouden het 
curriculum dus moeten omdraaien, beginnen met echte problemen die de intrinsieke motivatie van studenten aanspreken en de passie voor biomedische wetenschappen laten opbloeien. Problem Based Learning, probleemgestuurd onderwijs, wordt dan Passion Based Learning, passiegestuurd onderwijs. Zoals ik al eerder noemde, in het nieuwe bachelorprogramma willen we een groot aantal keuzemogelijkheden inbouwen waardoor studenten meer invloed hebben op hun opleiding, beter begrijpen waarom iets op het programma staat en eerder zichzelf de vraag stellen 'wat wil ik nu eigenlijk'. Als je weet wat je wilt, kun je bewuster keuzes maken, en heeft het ook zin de vraag te stellen of je door je mobiel geleefd wilt worden, of dat je je leven zelf ter hand neemt. Moed speelt ook in een studentenleven een rol.

Wat ik $\mathrm{u}$ heb laten zien is dat we een nieuw programma aan het ontwikkelen zijn, en dat we daarbij proberen om eerste een aantal doelstellingen te formuleren (figuur 1 ) en vervolgens nagaan welke evidenties we kunnen gebruiken om het programma zo goed mogelijk in

\section{Karakteristieken Ontwikkelingen}

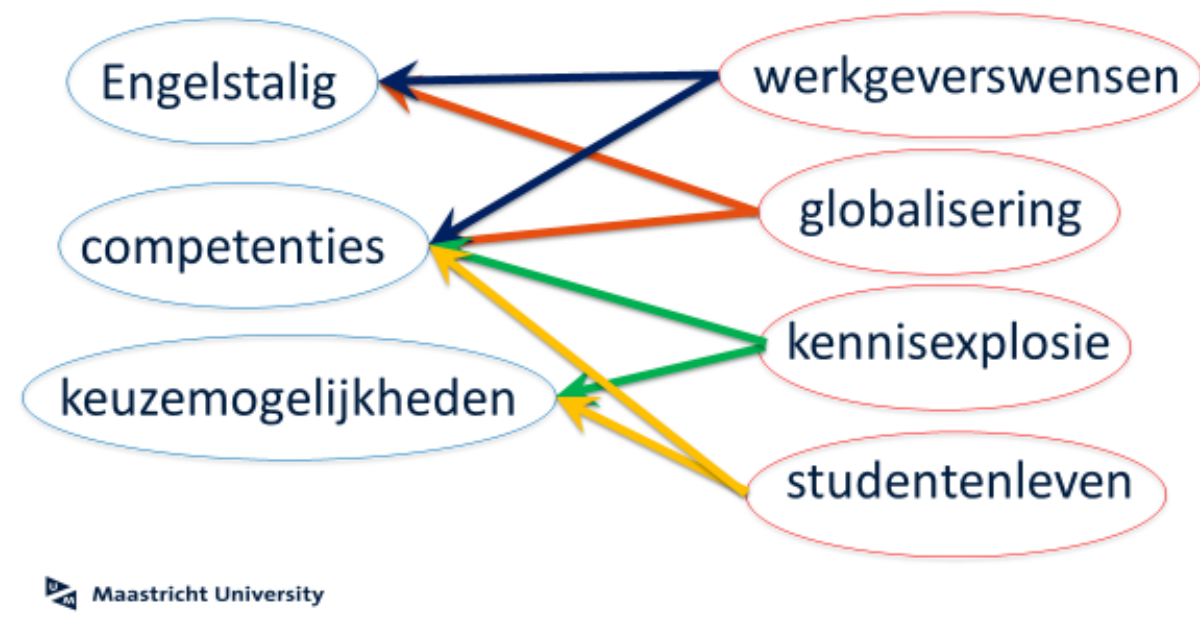

Figuur 1: Overzicht van de karakteristieken van het vernieuwde bachelorprogramma Biomedical Sciences en de ontwikkelingen die ten grondslag liggen aan deze karakteristieken. 
te richten. $U$ heeft wellicht af en toe de wenkbrauwen gefronst en gedachten 'dat is ook niet consequent' of juist 'jee, kan dat wel?' Beide geven aan dat het moed vraagt om een programma consequent in te richten en dat het niet altijd makkelijk is om de nodige hoeveel moed op te brengen. Maar als we die moed wel opbrengen krijgen we een programma waarin studenten met meer plezier studenten en beter voorbereid zijn op de arbeidsmarkt

\section{Bewogen door Onderwijs, staan in onderwijsgroepen}

In het tweede project dat ik met u wil bespreken gaat het over onderzoek waarin de vraag centraal staat of alledaags bewegen effect heeft op gezondheid en op cognitieve en academische prestaties. Dus bewegen als doping, in plaats van doping om te bewegen. We zijn op dit gebied met een aantal projecten bezig. Vanuit een interfacultaire onderzoeksgroep werken we aan het project 'De gezonde basisschool van de toekomst'. Daarin onderzoeken we, samen met een groot aantal partners, op een aantal basisscholen in Parkstad Limburg of meer bewegen en gezondere voeding de gezondheid, schoolprestaties en algemeen welzijn positief beïnvloeden. In een samenwerkingsverband met de Vrije Universiteit, de Open Universiteit en een aantal MBO-instelling, dat geleid wordt door Renate de Groot, gaan we onderzoeken of actievere onderwijsvormen in het MBO leidt tot betere leerprestaties en meer gezondheid. Het project dat ik wat uitgebreider met $u$ wil bespreken gaat over actief onderwijs binnen de UM. Omdat goed uit te leggen, neem ik u eerst mee naar het onderzoek dat we de afgelopen jaren gedaan hebben, dat ging over de invloed van zitten op gezondheid. U kent wellicht de Nederlandse Norm Gezond Bewegen? Die norm stelt dat je elke dag een half uur matig tot intensief moet bewegen. Deze norm is vooral ingegeven door het idee dat de energie die je door te eten dagelijks opneemt, ook weer verbruikt moet worden. Voor de doorsneemens, die normaal eet, geldt, dat dat lukt als je een half uur intensief beweegt en de rest van de dag zittend doorbrengt. 
De Beweegnorm negeert dat niet iedereen van sporten houdt. Daarnaast gaat de Beweegnorm voorbij aan het feit dat de effecten van trainen maar beperkt houdbaar zijn. Door inspanning gewonnen spiermassa en fitheid gaan rap weer verloren als je even niets doet. En dat is maar goed ook, want anders zaten we hier in een zaal vol Hulkjes, elke keer sporten zou leiden tot meer spierkracht, spiermassa en fitheid, zonder dat het verloren zou gaan. In de biologie heet dat Use it or lose it, dat wat je niet gebruikt wordt opgeruimd, afgebroken. Met dat idee van use it or lose it in het achterhoofd hebben we ons afgevraagd wat gebeurd er in de 23,5uur per dag dat je van de beweegnorm niets hoeft te doen? Kun je die tijd niet slimmer gebruiken, en zeker als je weet dat veel mensen niet van sporten houden. In een reeks studies hebben we onderzocht wat het effect van minder zitten op gezondheid is, minder zitten in plaats van een half uur sporten. We lieten proefpersonen drie regimes volgen, één waarbij ze vier dagen lang veel moesten zitten, zonder te sporten, één waarbij ze veel zaten en dagelijks één uur moesten sporten, dus dubbel zoveel als de Beweegnorm, en één derde waarbij ze het energiegebruik van dat sporten aan alledaagse, laag intensieve, maar wel langer durende activiteiten moesten 'uitgeven' (Duvivier et al., 2013). Wat we zagen was verrassend: een aantal belangrijke gezondheidsmarkers was verbeterd bij minder zitten, maar was in de sportconditie gelijk aan de zitconditie. Een belangrijke uitkomstmaat was insulinegevoeligheid. Insuline is een hormoon dat er voor zorgt dat suikers vanuit het bloed in de lichaamscellen opgenomen worden, zodat die cellen energie krijgen om hun werk te doen. Bij mensen met suikerziekte is de gevoeligheid van de cellen voor insuline afgenomen; en die verbeterde dus in de sit-less conditie. We hebben dit onderzoek herhaald in verschillende populaties: bij gezonde studenten, bij wat oudere mensen met overgewicht en bij oudere mensen met suikerziekte. En steeds vonden we gelijke resultaten. Van deze studies hebben we geleerd: 
- dat je niet hoeft te sporten om gezond te zijn en te blijven, voldoende alledaags bewegen volstaat

- dat veel en langdurig zitten ongezond is.

Wat betekent dit alles voor bewegen en leren? Er zijn in de afgelopen decennia al de nodige studies verricht die gekeken hebben naar de relatie tussen sporten en cognitief functioneren. Als ik het over cognitieve processen heb, kunt u denken aan zaken als geheugen, concentratie en aandacht. Maar dit soort studies zijn uitgevoerd bij kinderen of bij ouderen mensen, niet of nauwelijks bij jong volwassenen, studenten. En ook is niet onderzocht wat de invloed van laag intensieve activiteit is. Wat we onder meer al weten is dat insuline ook in de hersenen een belangrijke rol speelt. Dus gezien het feit dat we in de eerste studie vonden dat insulinegevoeligheid verbetert als je gewoon alledaags beweegt, is de gedachte dat dit ook invloed heeft op cognitieve processen bij jong volwassenen logisch.

De tweede aanleiding voor dit project is wat practischer van aard. Een aantal collega's hebben zich de vraag gesteld, als we weten dat zitten zo ongezond is, waarom laten we onze studenten dan zoveel zitten, kunnen we daar niet iets aan doen. Zo prikkelt Stef Kremers studenten om in de pauze te gaan staan, hij noemt dat tijd om te stuffen (Rutten et al., 2013) en Roy Erkens en Nicolai Manie hebben het helemaal serieus aangepakt, zij hebben staande onderwijsgroepen ingevoerd. Ik zal kort het Maastrichtse onderwijssysteem toelichten. In het Maastrichtse onderwijs staan zogenoemde onderwijsgroepen centraal. Studenten komen 2 maal per week bijeen in een groep van 10-12 studenten. Tijdens de eerste bijeenkomst krijgen ze een probleem voorgelegd. Dat probleem moet hen aanzetten tot studeren. Het eerste wat ze doen in zo'n bijeenkomst is samen nadenken over wat ze al weten van het probleem, een soort brainstorm. $U$ zult begrijpen dat het in zo'n brainstorm harder waait als er bereidheid is om samen te werken en als er variatie in voorkennis in de groep is. Na de brainstorm gaan ze, weer samen, hun ideeën en 
concepten ordenen en bespreken ze vervolgens wat ze gaan bestuderen en wat ze willen leren. Dan gaan ze naar huis of naar de bibliotheek om informatie te vinden en te ordenen. In de tweede bijeenkomst delen en bediscussiëren ze hun bevindingen en komen ze tot een gezamenlijke eindconclusie. Ik hoop dat $u$ aan de hand van deze schets begrijpt dat de groep en dus groepsprocessen cruciaal zijn in dit onderwijssysteem. Hoewel Erkens en Manie in eerste instantie geinteresseerd waren in gezondheidseffecten, hebben ze die niet meteen onderzocht, maar hebben ze eerst maar eens gekeken wat er in de onderwijsgroepen gebeurde. Wat opviel was dat de bijeenkomsten langer duurden, dat studenten dieper leken te leren, dat het whiteboard meer gebruikt werd en dat de discussies meer diepgang hadden. Zoals gezegd dit was geen echt wetenschappelijk onderzoek, en zeker niet dubbelblind of netjes genormaliseerd en gestandaardiseerd. Maar toch een ervaring die ons aan het denken gezet heeft niet in de laatste plaats omdat groepsdynamiek in het Maastrichtse onderwijssysteem een belangrijke en daarmee interessante factor is. In de literatuur zijn een paar studies die aansluiten bij onze eerste bevindingen over groepsdynamiek. Er zijn een paar studies die laten zien dat mensen die actief zijn creatiever zijn (Oppezzo and Schwartz, 2014). Creativiteit, ideeën kunnen combineren tot nieuwe toepassingen en concepten is iets wat in een onderwijsgroepsbijeenkomst van groot belang is. Ook is er onderzoek dat laat zien dat studenten die staand een probleem oplosten meer geneigd waren om samen te werken dan zittende studenten (Knight and Baer, 2014). Geprikkeld door deze ervaringen zullen we de komende jaren gaan onderzoeken of staan in onderwijsgroepen leidt tot beter cognitief functioneren, tot meer creativiteit en tot meer samenwerking in onderwijsgroepen, en uiteindelijk ook tot betere studieresultaten. Natuurlijk zullen we daarbij ook in het oog houden of dat gezondheidseffecten met zich meebrengt. We weten weliswaar dat het onderbreken van zitten gezond is, maar de vraag is of 2 keer 2 uur extra staan per week een substantiële bijdrage is, en ook weten we niet of die 2 keer 2 uur aanzetten tot meer staan tijdens de 
andere activiteiten, of dat ze juist op andere momenten van de dag zwaar gecompenseerd worden door extra zitgedrag.

Een van de eerste zaken die ik in deze oratie benoemde was het belang van kennis, dat kennis het leven een beetje voorspelbaarder maakt. Ik zet daar kennis af tegen ervaringen. Dit laatste project laat zien dat ook ervaringen waardevol kunnen zijn. De ervaringen uit de pilotstudie van Roy Erkens en Nicolai Manie sturen ons denken over de effecten van staan in een nieuwe richting. Met dit nieuwe onderzoek zullen we bijdragen aan nieuwe kennis.

Die nieuwe kennis, maar ook kennis die we allang hebben, zal ook de universiteit uitdagen moed te tonen, invulling te geven aan 'to practice what you preach'. Een universiteit die gezondheidswetenschappelijke kennis vergaart dient naar mijn mening expliciet en actief gezond gedrag te promoten en mogelijk te maken. Nu nog worden onze gebouwen gekarakteriseerd door afgesloten kamertjes die op lange gangen uitkomen, niet bepaald een inrichting waar je een broeinest van creativiteit en samenwerking verwacht. In die kamertjes staan dan veelal tafels en stoelen, zitten is de norm. Het kan ook anders, ook dit is de universiteit Maastricht, open gangen en zelfs helemaal open ruimtes, en sommigen die hun eigen stabureau geregeld hebben. Wanneer de universiteit haar kennis over gezond gedrag en een gezonde omgeving consequent uitdraagt zou zij zich kunnen profileren als Maastricht University, the healty university. Niet alleen een universiteit die een breed scala gezondheidgerelateerde opleidingen aanbiedt en vooraanstaand onderzoek op dit terrein leidt, maar ook een universiteit die optimaal zorg draagt voor het welzijn van haar studenten en medewerkers en daar voor gaat staan. 


\section{Mens sana in corpore sano}

Het leidmotief van mjin rede was 'moed', dat is u beslist niet ontgaan. Die moed heb ik in verband gebracht met onderwijs, bewegen en uiteindelijk ook met leren in striktere zin. In de eerste eeuw van de westerse jaartelling schreef Juvenalis al een gedicht hierover. $U$ kent wellicht uit dit gedicht de regel Mens sana in corpore sano, een gezonde geest in een gezond lichaam. Veelal wordt deze regel misbruikt om mensen tot sporten aan te zetten, dat zou goed voor de geest zijn. Wie het hele gedicht van Juvenalis leest ontdekt dat hij de goden vraagt om naast een gezond lichaam een gezonde geest te mogen hebben, en met een gezonde geest bedoelt hij moedig te zijn.

Moedig te zijn als docerende onderzoeker om recente kennis over onderwijs te gebruiken.

Moedig te zijn als onderwijsmaker om kritisch te blijven kijken naar de vernieuwingen die zijn ingezet en te blijven monitoren of ze werken. Moedig te zijn als universiteit om te gaan staan voor de kennis die je genereert.

Ik begrijp en weet dat moedig zijn niet altijd eenvoudig is, maar wanneer het lastig wordt, dan is altijd Loesje nog om te rade te gaan: Streef onbekommert naar het ideale!

\section{Dankwoord}

Alvorens ik het woord terug geef aan de prorector wil ik graag een aantal mensen bedanken. Om op de plek te komen waar ik nu staat heb hulp van velen gehad en met velen mogen samenwerken, en gelukkig mag ik dat nog steeds. Er zijn veel schouders waarop ik mag staan, en die mij geholpen hebben dit uitzicht te krijgen.

De Stichting Wetenschapsbeoefening UM, het College van Bestuur van deze Universiteit, en het College van Toezicht wil ik danken voor het in mij 
gestelde vertrouwen. Speciaal wil ik daarbij Albert Scherpbier, Mirjam Oude Egbrink en Ineke Wolfhagen bedanken voor het wijzen van de weg op dit pad van een onderwijscarriere. Daarbij wil ik ook Harm Kuipers noemen die me al vele jaren geleden binnen de vakgroep Bewegingswetenschappen relevante onderwijstaken toevertrouwde.

Het is ongeveer 50 jaar geleden dat ik officiëel naar de kleuterschool mocht, sinds die tijd heb ik van vele juffen, meesters, docenten, trainers en coaches iets mogen leren. Een aantal van hen is vandaag hier aanwezig, soms van heel lang geleden. Ik ben heel vereerd dat jullie vandaag de moeite genomen hebben om hier naar toe te komen en dank jullie van harte voor je geduld en toewijding.

Dan zijn er collega's met wie ik samen aan onderzoeksprojecten werk, het is heerlijk om verschillende disciplines te kunnen combineren en samen over nieuwe stappen na te denken. Nobelprijswinnaar Feringa had vergeleek onderzoek doen eerder deze week als ronddwalen in de speeltuin van de wetenschap. Inderdaad, onderzoek is als spelen, je doet het voor for its own sake. Ik dank jullie voor de vriendschap en collegialiteit in deze speeltuin.

Dan zijn er de echte werkpaarden, de AiO's die ik heb mogen begeleiden of nog mag begeleiden. Werkpaard is dit geval een eretitel, in een roeiacht zijn dat de mannen en vrouwen in het middenschip, ze worden de engine room genoemd. Zonder engine room komt geen acht van haar plaats, en geen onderzoek van de grond. Het was een genoegen om jullie te mogen begeleiden en zonder jullie inzetten zouden we nu veel minder weten.

Bij de ontwikkeling en vormgeving van het nieuwe curriculum is een grote groep collega's nauw betrokken. Mariëtte Cruijssen, Marjan Govaerts, Geja Hageman, Sylvia Heeneman, Daniel van den Hove, Leo Köhler, Tom Kuiper, Ronald Mensink, Herma Roebertsen, Mariëlla Swinnen, Juanita 
Vernooy en Willem Voncken een belangrijke rol gespeeld, ik wil jullie heel hartelijk danken voor je inzet en betrokkenheid.

Ook ben ik de vele blokplanningsgroepleden en tutoren die hun best doen om het programma daadwerkelijk te laten lopen zeer erkentelijk; zonder jullie staat het ganse raderwerk stil. Dit ondanks het feit dat in deze beginfase er nog veel losse eindje zijn.

Mijn universitaire thuis, de vakgroep Bewegingswetenschappen, zo noem ik die nog maar even, is de laatste jaren goed opgeschud. De nieuwe groep in wording is zich aan het ontwikkeling tot een mooie nieuw thuis, waar veel onderling vertrouwen is. Dat voelt heel goed. Bij de vakgroep aangekomen, zijn er drie mensen die ik speciaal wil bedanken, Désirée Brands, Harry Wandler en Paul Willems verdienen een speciale pluim op hun hoed. Dank je wel, voor jullie jarenlange, onvoorwaardelijk steun. Wilfred, we zijn onder hetzelfde gesternte geboren, onze levenspaden zijn aan de VU dichtbij elkaar in de buurt geweest, maar kruisten elkaar pas enkele jaren geleden in Maastricht. In de Master hebben we de komende jaren een opdracht te vervullen. Ik kijk er naar uit om dat samen op te pakken.

Kenneth, we zijn niet onder hetzelfde gesternte, maar wel op dezelfde dag van het jaar geboren. We hebben de afgelopen jaren samen een mooi team opgebouwd, van waaruit we ieder weer een eigen weg konden inslaan. Je collegialiteit voelt als vriendschap.

Nicolaas Schaper kon hier vandaag helaas niet zijn, dat is jammer, vooral omdat ik hem graag had willen zeggen hoe zeer ik onze samenwerking waardeer. Met enige onregelmaat hebben we met-de-benen-op-tafel sessies waarin de breinen heerlijk kunnen stormen. Het mooiste resultaat tot nu toe is ons gezamenlijke minder-zitten onderzoek, ik weet dat we daarin origineel zijn geweest. Ik hoop dat we nog vaak samen de benen op tafel kunnen leggen. 
Leo, toen we drie jaar geleden de verantwoordelijkheid voor BMW gingen delen, moesten we even onze draai samen vinden. Ik vind dat we inmiddels een goed team zijn. Ondanks al je drukte en ijver, ben je een baken van rust, met een grote gevoel voor relativering en zelfreflectie. Dat alles maakt het voor mij een plezier om met je te mogen samenwerken. En voor wie nog mocht denken dat Duitsers geen humor hebben, ga eens met Leo praten.

Herma, al bijna 20 jaar delen we met enige regelmaat een trein en onze ideeën, zorgen en plannen over onderwijs. De laatste jaren ben je steeds meer een reizende onderwijsvraagbaak geworden, je deelt je zorgen over alles wat nog niet af is, en helpt me om al te wilde plannen tot realistische proporties terug brengt, of juist andersom, je zorgt dat een aardig idee, krachtig in een onderwijskundig kader geplaatst wordt en daardoor gaat werken. Je rol in het BMW curriculum is groot. De vriendschap die uit onze werkrelaties is voortgekomen en die zich uitstrekt naar onze families, is een kers op de taart.

Lieve Mams, ik weet dat je trots bent, maar ik geloof dat ik eerder trots op jouw moet zijn. Ik zou je kunnen bedanken voor alle keren dat je op zieke kinderen kwam passen en andere zorgtaken op je nam, maar eigenlijk is dat niets vergeleken bij de dankbaarheid die ik voel voor de ruimte, vrijheid en mogelijkheden die jij en natuurlijk ook pa mij al een levenlang geven om te worden wie ik ben. Ik heb lang nagedacht met welk Nederlands woord ik dit zou kunnen zeggen, maar ik heb het niet gevonden. Je zult het zo meteen met een hele dikke knuffel moeten doen.

Maud, Lotte, en Angelique, jullie vinden me soms een rare vogel, dat klopt, dat komt omdat jullie de allerliefste uilskuikens zijn. Ik geniet er elke dag bijzonder van als ik zie hoe jullie je vleugels uitslaan en de wijde wereld ontdekken. Enjoy, and ....

Lieve Anne, ik zei aan het begin van het dankwoord dat het over schouders ging om op te staan, die mij hier naar toe gedragen hebben. 
Die van jou, jouw schouders zijn de allerbelangrijkste en sterkste, zonder jouw was het hier vanmiddag leeg en stil geweest, je hebt me geinspireerd om te groeien en daarbij alle geduld van de wereld betracht. We horen nu een empty nest syndroom te hebben, maar als jij thuis bent voelt dat zeker niet zo.

Bon Courage a tous, ik heb gezegd! 


\section{Referenties}

De Boer, M., van den Bosch, J., Freriks, C., Soudant, L en Pouwelse, A. Er is lef voor nodig om nu student te zijn. Observant, 2016, 36(23):8-9.

Duvivier, B.M.F.M., Schaper, N.C., Bremers, M.A., Van Crombrugge, G., Menheere, P.P.C.A., Kars, M. en Savelberg, H.H.C.M. Minimal intensity physical activity (standing and walking) of longer duration improves insulin action and plasma lipids more than shorter periods of moderate to vigorous exercise (cycling) in sedentary subjects when energy expenditure is comparable. PLOS ONE, 2013, 8(2): e55542.

Knight, A. P., \& Baer, M. Get Up, Stand Up: The effects of a non-sedentary workspace on information elaboration and group performance. Social Psychological and Personality Science, 2014, 5:910-917.

Levin, B. Leadership for evidence informed education. School Leadership and Management, 2010, 30(4):304-315.

NIBI, Nederlandse Instituut voor Biologie. Arbeidsmarktonderzoek Biowetenschappen en Biomedische Wetenschappen in Nederland, 2014.

Oppezzo, M., \& Schwartz, D. L. Give your ideas some legs: The positive effect of walking on creative thinking. Journal of Experimental Psychology: Learning, Memory, and Cognition, 2014, 40: 1142-1152.

Pink, D.H. Drive. The surprising truth about what motivates us. London: Penguin Books Ltd, 2011.

Rutten, G.M., Savelberg, H.H., Biddle, S. J. \& Kremers, S.P. Interrupting long periods of sitting: Good STUFF. International Journal of Behavioral Nutrition and Physical Activity, 2013, 10(1): 1 .

Ryan, R.M. and Deci, E.L. Self-determination theory and the facilitation of intrinsic motivation, social development, and well-being. American Psychologist, 55: 68-78, 2000.

Thomas, C. Sammy kijk omhoog. De groene Amsterdammer, 2016, 140(36): 20-23

Wagner, T. The global achievement gap: Why even our best schools don't teach the new survival skills our children need-and what we can do about is. New York: Basic Books, 2010. 